\title{
Factors that negatively interfere with the coverage of antitetanus vaccination in the
}

\section{elderly: an integrative review}

\author{
Fatores que interferem negativamente na cobertura da vacinação antitetânica em idosos: uma \\ revisão integrativa \\ Factores que interfieren negativamente en la cobertura de vacunación contra el tétano en el \\ anciano: una revisión integrativa
}

Received: 01/27/2022 | Reviewed: 02/05/2022 | Accept: 02/11/2022 | Published: 02/16/2022

\author{
Maria Taís da Silva Santos \\ ORCID: https://orcid.org/0000-0003-3626-174X \\ Federal University of Campina Grande, Brazil \\ E-mail: tais0674@gmail.com \\ Maria Tereza Leite Mariano \\ ORCID: https://orcid.org/0000-0002-3835-2285 \\ Federal University of Campina Grande, Brazil \\ E-mail: maria.mariano@estudante.ufcg.edu.br \\ Thamara Rodrigues de Melo \\ ORCID: https://orcid.org/0000-0001-6540-9585 \\ Unifacisa University Center, Brazil \\ E-mail: th.rmelo@outlook.com \\ Sávio Benvindo Ferreira \\ ORCID: https://orcid.org/0000-0001-8838-4755 \\ Federal University of Campina Grande, Brazil \\ E-mail: savio.benvindo@professor.ufcg.edu.br \\ Rafaelle Cavalcante de Lira \\ ORCID: https://orcid.org/0000-0002-0360-1157 \\ Federal University of Campina Grande, Brazil \\ E-mail: rafaelle.cavalcante@professor.ufcg.edu.br
}

\begin{abstract}
Tetanus is an infectious and non-contagious disease capable of causing a state of hyperexcitability in the central nervous system. In order to prevent the development of the infection, the tetanus vaccine was implemented. However, for effective protection, a complete and adequate immunization is necessary. The aim of the study was to identify the factors that can interfere with the tetanus vaccination scheme in the elderly population. This is an integrative, retrospective, descriptive-exploratory literature review with a qualitative approach, carried out through the Portal de Periódicos CAPES. After the search, 2,313 studies were found, of which 18 were eligible for the final sample. Factors that negatively affect tetanus vaccine coverage in the elderly population were identified as the number of incomplete doses and the absence of tetanus booster; absence of vaccination campaigns and socioeconomic and demographic aspects. Therefore, it was determined that tetanus is a disease that can cause serious complications and concerns to health systems, with the elderly being the population most affected by the infection, both due to changes in their physiology and the decrease in the levels of protective antibodies.
\end{abstract}

Keywords: Tetanus; Elderly; Immunization; Epidemiology.

\section{Resumo}

O tétano é uma doença infecciosa e não contagiosa, capaz de provocar um estado de hiperexcitabilidade do sistema nervoso central. Com a finalidade de prevenir o desenvolvimento da infecção foi implementada a vacina antitetânica. No entanto, para eficácia na proteção é necessária uma imunização completa e adequada. O objetivo do estudo foi identificar os fatores que podem interferir no esquema de vacinação contra o tétano na população idosa. Trata-se de uma revisão integrativa de literatura, retrospectiva, de cunho descritivo-exploratório com abordagem qualitativa, realizada através do Portal de Periódicos CAPES. Após a busca, foram encontrados 2.313 estudos, dos quais 18 foram elegíveis para a amostra final. Identificou-se como fatores que afetam negativamente a cobertura vacinal de tétano no público idoso o número de doses incompletas e ausência de reforço antitetânico; ausência de campanhas de vacinação e aspectos socioeconômicos e demográficos. Diante disso, determinou-se que o tétano é uma doença que pode provocar graves complicações e preocupações aos sistemas de saúde, sendo os idosos o público mais acometido pela infecção, tanto devido às mudanças em sua fisiologia quanto à diminuição dos níveis de anticorpos protetores.

Palavras-chave: Tétano; Idoso; Imunização; Epidemiologia. 


\section{Resumen}

El tétanos es una enfermedad infecciosa y no contagiosa, capaz de provocar un estado de hiperexcitabilidad del sistema nervioso central. Para prevenir el desarrollo de la infección, se implementó la vacuna contra el tétanos. Sin embargo, para una protección eficaz, se requiere una inmunización completa y adecuada. El objetivo del estudio fue identificar los factores que pueden interferir con el calendario de vacunación antitetánica en la población anciana. Se trata de una revisión bibliográfica integradora, retrospectiva, descriptiva-exploratoria con enfoque cualitativo, realizada a través del Portal de Periódicos de la CAPES. Después de la búsqueda, se encontraron 2.313 estudios, de los cuales 18 fueron elegibles para la muestra final. Se identificaron como factores que inciden negativamente en la cobertura de vacunación antitetánica en la población anciana el número de dosis incompletas y la ausencia de refuerzo antitetánico; ausencia de campañas de vacunación y aspectos socioeconómicos y demográficos. Por lo que se determinó que el tétanos es una enfermedad que puede causar serias complicaciones y preocupaciones a los sistemas de salud, siendo los adultos mayores el público más afectado por la infección, tanto por cambios en su físiología como por la disminución de los niveles de anticuerpos protectores.

Palabras clave: Tétanos; Anciano; Inmunización; Epidemiología.

\section{Introduction}

Clostridium tetani, an anaerobic gram-positive bacillus, sporulated and producing an exotoxin called tetanospasmin, capable of causing a state of hyperexcitability of the central nervous system. This bacteria can be found in feces, dust, soil, tree branches, decaying water, animal intestinal tracts, among other surfaces. Necrotic tissues, foreign bodies, ischemia and infection are factors that decrease the oxidation-reduction potential and, thus, establish the favorable circumstances for the development of the bacillus (Ministério da Saúde, 2015; Tavares \& Marinho, 2007).

In order to prevent the development of infection by this microorganism, the tetanus vaccine was developed. It is able to generate immunity by producing antibodies against tetanospasmin and therefore makes tetanus a preventable disease. However, for effective protection, a primary immunization, which consists of 3 doses, is required. The time interval for administering the vaccine varies in different countries. In Brazil, in children it occurs at two, four and six months, later, at 15 months and between 4 and 6 years of age, a booster should be applied; adults who have never been immunized against tetanus should receive three administrations of the dual adult (dT) vaccine, with an interval of one month between doses. Worldwide, a tetanus toxoid booster is recommended every decade so that protective antibody levels remain continuous (Ministério da Saúde, 2019; Cossutta, 2017; Sahan et al., 2019).

Despite this therapeutic resource, according to the World Health Organization (WHO), 50,000 cases of tetanus are registered annually. In Brazil, in 2000 the incidence rate was 0.32 per 100,000 inhabitants, currently this rate is 0.15 , which shows a significant reduction. According to the Notifiable Diseases Information System (SINAN), 2939 confirmed cases of accidental tetanus were reported in the period between 2007 and 2016, with 973 deaths from this infection in the same period. In 2017, there were 230 cases and 70 deaths from tetanus. Although there has been a decrease in the appearance of new cases in recent years, the fatality rate remains the same, being around $30 \%$, since the 1980 s. This factor, added to the high cost of treatment, makes this infection still considered a serious public health problem (Ministério da Saúde, 2017).

According to the Pan American Health Organization (PAHO, 2019), maternal and neonatal tetanus in the Americas has been eliminated, showing the effectiveness of childhood immunization programs and prenatal care. On the other hand, cases of accidental tetanus continue to appear in adults, especially in elderly people who are not adequately immunized. This epidemiological behavior of the disease occurs especially in developed countries, where the elderly constitute the main risk group for the development of the disease. In Brazil, according to epidemiological data, $72 \%$ of registered cases of tetanus occurred in the age group between 35 and 79 years old and, of these, the number of deaths in the elderly corresponded to $70 \%$ (Ministério da Saúde, 2015; PAHO, 2019).

It is noticed that the elderly are more vulnerable to tetanus infection due to the decrease in the levels of tetanus antitoxins, which occurs due to physiological changes inherent to the aging process, added to inadequate vaccination coverage 
and negligence in the booster doses of tetanus toxoid. Worldwide, epidemiological data on age distribution and tetanus vaccination are scarce and favor neonatal tetanus (Sahan et al., 2019). As the elderly population is the main group affected by tetanus due to the incomplete vaccination schedule, the need to investigate: What variables can interfere with the tetanus vaccination scheme in the elderly population? Thus, this study aims to identify the factors that can interfere with the tetanus vaccination scheme in the elderly population.

It emphasizes the importance of researching the aspects that are capable of affecting tetanus immunization and make the elderly population the main risk group for the disease, since by identifying these factors it is possible to guide the creation of policies campaigns aimed at vaccination campaigns for the adult public, promoting the health of the elderly and improvements in their quality of life.

\section{Methodology}

\subsection{Study}

This is an integrative, retrospective, descriptive-exploratory literature review with a qualitative approach, through a bibliographic review, which summarizes existing scientific materials and provides the space for their critical analysis. This type of study is able to gather evidence from several studies, making it possible to update and assist health professionals in decision-making (Souza et al., 2010).

To prepare this review, six distinct and sequential steps recommended in the literature were followed: 1) definition of the research topic and question; 2) establishment of inclusion and exclusion criteria; 3) definition of the information to be extracted from the selected studies; 4) evaluation of the studies included in the review; 5) analysis and interpretation of results and 6) presentation of the knowledge review/synthesis (Mendes et al., 2008).

Based on the reading of updated national and international epidemiological bulletins about confirmed tetanus cases, it was observed that the incidence was higher in the elderly population, which motivated research and hypotheses about which aspects were responsible for this scenario. Thus, the question that guided the study was: "Which variables can interfere with the tetanus vaccination scheme in the elderly population?".

\subsection{Inclusion and Exclusion Criteria}

As inclusion criteria for the studies, we opted for articles available in full and free of charge, in Portuguese, English or Spanish, published from 2000 to 2020, since there are few recent publications that answer the guiding question. Exclusion criteria were: reviews of any style, articles that did not address the research topic or that did not answer the guiding question, studies in editorial format and duplicated articles in more than one database.

\subsection{Search and Screening of Studies}

To answer the study's guiding question, an electronic search was carried out on the Journal Portal of the Coordination for the Improvement of Higher Education Personnel (CAPES) in June and July 2020, using the intersection of the following Health Sciences Descriptors (DeCS ): "Tetanus"; "Old man"; "Immunization” and "Epidemiology", in Portuguese, English and Spanish, grouped by the Boolean operator "AND".

After the electronic search procedure, 2004 papers were found. Of these, 75 were excluded after applying the "languages" filter. Of the 1564 remaining articles, 272 were selected after reading the titles, from which those that matched the inclusion criteria were chosen, with 40 repeated articles being removed, to avoid duplication in the consolidation of data. Thus, 29 articles were pre-selected from the reading of titles and abstracts and the final sample consisted of 18 articles chosen after 
being fully read by the researchers, independently. It should be noted that new studies indexed after the search period were not considered.

Figure 1 shows the flowchart referring to the selection process of articles that were part of the final sample of this integrative literature review. In this study method, there is no need to submit to the Research Ethics Committee (CEP) as it is carried out exclusively with secondary sources.

Figure 1. Flowchart of the selection of studies for the integrative review on the factors that negatively affect the coverage of tetanus vaccination in the elderly.

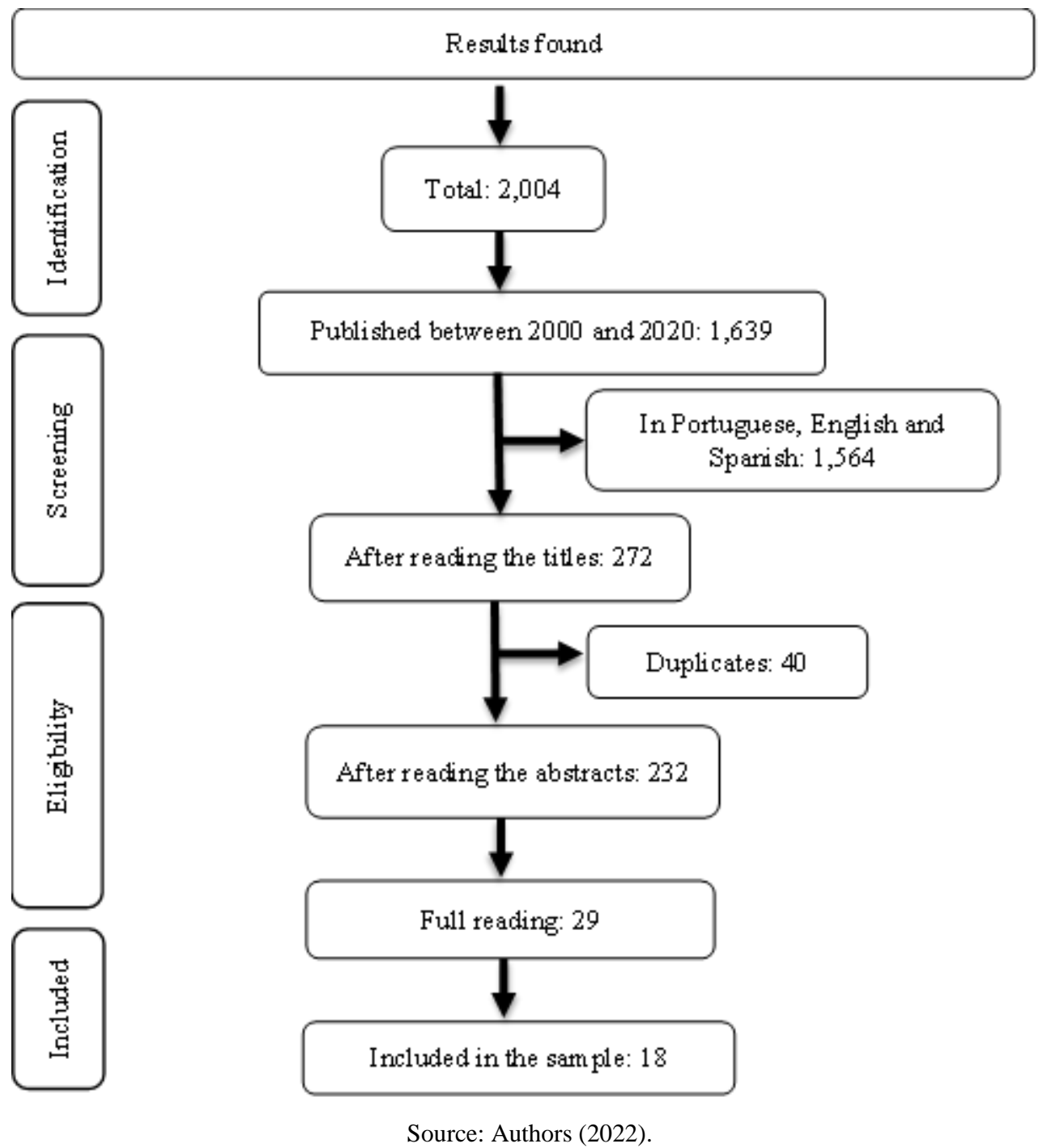

\section{Results and Discussion}

The final result of the research included studies carried out in 13 different countries: France (Mahieu et al., 2017), Mexico (Cruz-Hervet et al., 2013), England (Collins et al., 2016), Portugal (Castro et al., 2004; Moura \& Martins, 2019), Brazil (Feijão et al., 2007; Moraes \& Pedroso, 2003; Weckx et al., 2006), Turkey (Sahan et al., 2019), Austria (Weinberger et al., 2013), USA (Farnworth et al., 2012; Talan et al., 2004), Iran (Razzaghi et al, 2011), Italy (Filia et al., 2014; Valentino \& Rapisarda, 2001), Australia (Quinn \& McIntyre, 2007), Spain (Domínguez et al., 2007) and Canada (Halperin et al., 2015), in which $16.7 \%$ of the surveys were carried out in Brazil, followed by Portugal, USA and Italy, equally, with $11.1 \%$. 
To organize the articles that made up the sample, the instrument was used, including database, title, authors, year/country, study design and outcomes presented in Table 1, whose organization occurred in ascending order of the year of publication of the studies.

Table 1. Characterization of the sample articles according to Bases, Author(s), Year, Study design, Outcomes.

\begin{tabular}{|c|c|c|c|c|}
\hline Data base & Author(s) & Year & Study design & Outcomes \\
\hline Oxford Academic & $\begin{array}{l}\text { Valentino \& } \\
\text { Rapisarda }\end{array}$ & 2001 & Retrospective & $\begin{array}{l}\text { In this study, } 93.7 \% \text { of the studied portion } \\
\text { had never received a complete cycle of } \\
\text { vaccination, while the others had been } \\
\text { immunized } 20 \text { years ago. }\end{array}$ \\
\hline Scielo & $\begin{array}{l}\text { Moraes \& } \\
\text { Pedroso }\end{array}$ & 2003 & $\begin{array}{c}\text { Qualitative } \\
\text { observational }\end{array}$ & $\begin{array}{l}\text { In Brazil, the elderly are the only age } \\
\text { group that the tetanus mortality rate has } \\
\text { not reduced. }\end{array}$ \\
\hline Scopus & Castro et al. & 2004 & $\begin{array}{l}\text { Descriptive } \\
\text { exploratory }\end{array}$ & $\begin{array}{l}\text { The lack of encouragement to adhere to } \\
\text { vaccination and the lack of prophylaxis in } \\
\text { cases of injuries contribute to missed } \\
\text { opportunities for vaccination. }\end{array}$ \\
\hline Science Direct & Talan et al. & 2004 & $\begin{array}{l}\text { Observational } \\
\text { prospective }\end{array}$ & $\begin{array}{l}\text { The risk of tetanus persists in the elderly, } \\
\text { immigrants and people with a low level of } \\
\text { education, in addition to inadequate } \\
\text { immunization. }\end{array}$ \\
\hline Scielo & Weckx et al. & 2006 & $\begin{array}{l}\text { Comparative } \\
\text { observational }\end{array}$ & $\begin{array}{l}\text { No elderly had antibodies that provided } \\
\text { total protection against tetanus and only } \\
6 \% \text { had basic immunity. }\end{array}$ \\
\hline Scielo & Feijão et al. & 2007 & $\begin{array}{l}\text { Descriptive } \\
\text { Retrospective }\end{array}$ & $\begin{array}{l}\text { Individual, cultural, social, economic and } \\
\text { access to health services aspects influence } \\
\text { the inadequate tetanus vaccine coverage. }\end{array}$ \\
\hline Science Direct & $\begin{array}{l}\text { Quinn \& } \\
\text { McIntyre. }\end{array}$ & 2007 & Descriptive quantity & $\begin{array}{l}\text { In Australia, tetanus is primarily a disease } \\
\text { of the elderly. Tetanus vaccination, if } \\
\text { applied at age } 50 \text {, could prevent } 46 \% \text { of } \\
\text { hospitalizations and } 45 \% \text { of deaths. }\end{array}$ \\
\hline Web Of Science & Domínguez et al. & 2007 & Quantitative & $\begin{array}{l}\text { The prevalence of tetanus antibodies is } \\
\text { insufficient in adults over } 45 \text { years of age, } \\
\text { and all recent cases have occurred in } \\
\text { individuals over } 60 \text { years of age. }\end{array}$ \\
\hline DOAJ & Razzaghi et al. & 2011 & Transverse & $\begin{array}{l}\text { Antitoxin levels decreased with age. } \\
\text { Elderly people do not have protective } \\
\text { immunity against tetanus due to } \\
\text { incomplete vaccination coverage. }\end{array}$ \\
\hline Wiley Online Library & Farnworth et al. & 2012 & Retrospective & $\begin{array}{l}\text { Aging and low levels of immunity are } \\
\text { associated with the risk of tetanus } \\
\text { infection. }\end{array}$ \\
\hline Academic Search Premier & Weinberger et al. & 2013 & Exploratory & $\begin{array}{l}\text { Single-dose tetanus vaccination is not } \\
\text { able to promote lasting immunity in most } \\
\text { elderly people. }\end{array}$ \\
\hline Scielo & Cruz-Hervet et al. & 2013 & Descriptive quantity & $\begin{array}{l}\text { Education, place of residence, } \\
\text { socioeconomic status and speaking the } \\
\text { indigenous language are some of the } \\
\text { difficulties related to incomplete } \\
\text { vaccination schedules. }\end{array}$ \\
\hline Science Direct & Filia et al. & 2014 & $\begin{array}{l}\text { Descriptive } \\
\text { observational } \\
\text { quantitative }\end{array}$ & $\begin{array}{l}\text { Even with the availability of an effective } \\
\text { vaccine, the incidence of tetanus in Italy } \\
\text { is still high and has a high mortality rate, } \\
\text { especially in the elderly. }\end{array}$ \\
\hline Science Direct & Halperin et al. & 2015 & $\begin{array}{l}\text { Quali-quantitative, } \\
\text { sequential and } \\
\text { explanatory }\end{array}$ & $\begin{array}{l}\text { Immunization rates for the Tdap vaccine } \\
\text { remain below recommended due to little } \\
\text { knowledge about vaccination, especially } \\
\text { among the elderly. }\end{array}$ \\
\hline Cambridge Core & Collins et al. & 2016 & Descriptive quantity & $\begin{array}{l}\text { In England, most tetanus cases occurred } \\
\text { in unimmunized or partially immunized } \\
\text { elderly. }\end{array}$ \\
\hline PMC & Mahieu et al. & 2017 & $\begin{array}{l}\text { Multicentric } \\
\text { Retrospective }\end{array}$ & $\begin{array}{l}\text { Tetanus in France mainly affects elderly } \\
\text { patients. However, there was a low }\end{array}$ \\
\hline
\end{tabular}




\begin{tabular}{cccl}
\hline & & & \\
\hline J-Stage & Sahan et al. 2019 & Transverse & $\begin{array}{l}\text { The level of protective tetanus antibodies } \\
\text { decreases with advancing age, correlates } \\
\text { with the lack of information regarding } \\
\text { anti-tetanus reinforcement. }\end{array}$ \\
\hline Medline & Moura \& Martins 2019 & Transverse & $\begin{array}{l}\text { Low tetanus vaccination coverage was } \\
\text { identified in elderly immigrants. } \\
\text { Associated with incomplete vaccination } \\
\text { coverage are: low family income, region } \\
\text { of residence, citizenship and health } \\
\text { insurance. }\end{array}$ \\
\hline
\end{tabular}

Source: Authors (2022).

During the analysis of publications, it was observed in $83.3 \%$ of the studies that the elderly were the predominant audience among patients who contracted tetanus. Irregular vaccination coverage was one of the most relevant factors as an answer to why the elderly are more susceptible to tetanus. In addition to incomplete immunization, some conditions were also identified in research as responsible for the higher incidence of tetanus in the elderly population, namely: the change in physiology and the presence of chronic wounds (Castro et al., 2004; Collins et al., 2016; Farnworth et al., 2011; Feijão et al., 2007; Quinn \& McIntyre, 2007; Sahan et al., 2019; Talan et al., 2004).

As for physiology, aging causes the reduction of various reflexes and functional capacity such as muscle weakness, slow movement and decreased visual and auditory senses. These limitations increase the risk of domestic accidents, which can lead to different types of injuries. On the other hand, chronic wounds, low seroprotection against tetanus and lack of adequate care facilitate the inoculation of spores of the bacteria responsible for the infection (Farnworth et al., 2011; Feijão et al., 2007; Sahan et al., 2019).

Regarding gender, $50 \%$ of the studies did not mention an association between gender and tetanus cases. However, $44.4 \%$ of the articles showed that females were the most affected, compared to $55.6 \%$ that included men as the most affected group. This fact may be due to the fact that women receive doses of the vaccine while they are of reproductive age and when this period passes, they become susceptible to the disease due to the lack of booster (Feijão et al., 2007). Likewise, the absence of a vaccination campaign aimed at the male public makes them equally susceptible. In this way, vaccination will only take place in the event of an injury, when referred to the hospital or when required at their place of service, such as the military.

Regarding the type of wound, it was observed that there were several ways to contract the infection, such as: chronic ulcer in 22.2\% of the studies (Castro et al., 2004; Collins et al., 2016; Farnworth et al., 2011; Feijão et al., 2007); perforations in 22.2\% (Collins et al., 2016; Feijão et al., 2007; Filia et al., 2014; Valentino \& Rapisarda, 2001); injuries caused by injecting illicit drug administration in 16.7\% (Castro et al., 2004; Collins et al., 2016; Mahieu et al., 2017); lacerations in 16.7\% (Collins et al., 2016; Feijão et al., 2007; Filia et al., 2014); burns in 11.1\% (Collins et al., 2016; Feijão et al., 2007); excoriations in 11.1\% (Feijão et al., 2007; Valentino \& Rapisarda, 2001); surgical wounds in 11.1\% (Farnworth et al., 2011; Feijão et al., 2007) and animal bites or scratches in 5.5\% (Collins et al., 2016). In addition to these, cases of contamination by the mouth were also noticed, although this form is rarely mentioned in the literature (Feijão et al., 2007).

It is important to mention that, despite the reduction in the number of tetanus cases over time, the lethality coefficient remains high in the elderly population, with $47.6 \%$ in the $65-79$ age group and $52.3 \%$ in the elderly population. 80 years or more, being so high that for every 100 people infected, approximately 40 die. The seriousness is due to numerous complications, which lead to hospitalizations with clearly higher costs when compared to the total cost of the vaccine; since in Brazil, on average 202 people are hospitalized annually, where the individual cost for treatment is around 5,022.32 real, while the dose of the vaccine costs 41 cents, so, per year, the cost of hospitalizations is equivalent to 24 million doses of vaccine 
(Ministério da Saúde, 2018). This fact highlights the importance of expanding immunization rates to reduce the severity and lethality of the infection in the elderly, who constitute the main risk group.

Furthermore, it was observed that there was an association between incomplete vaccination coverage and different aspects that induce this irregularity in the vaccination schedule. Therefore, according to the data collected for the construction of the research, the factors that interfere with the tetanus vaccination status in the elderly population are:

\subsection{Incomplete vaccination}

It is known that to have complete immunity against tetanus, it is necessary to have three doses of tetanus vaccine and to be reinforced every ten years. This number of incomplete doses is a factor that occurs due to several aspects, especially the lack of information, in which the elderly is not aware of how many doses are needed or that need to be reinforced every 10 years, and therefore, they do not complete the cycle, making immunization inadequate (Sahan et al., 2019). Another explanation found was that many individuals were unaware that the Tdap vaccine was financed by the government and, even if they knew, they had no intention of being immunized (Halperin et al., 2015).

Importantly, the Tdap vaccine can protect adolescents and adults against tetanus, diphtheria and whooping cough, and is routinely given at 11 or 12 years of age or taken as soon as possible. This vaccine is especially important for healthcare professionals and anyone who has close contact with a baby younger than 12 months. In pregnant women, women should take a dose of Tdap during each pregnancy to protect the newborn against whooping cough, as babies are most at risk for serious, life-threatening complications from whooping cough. Another vaccine, called $\mathrm{Td}$, protects against tetanus and diphtheria, but not against whooping cough, and a Td booster should be taken every 10 years, including the elderly. In fact, Tdap can be taken as one of these boosters if you have never taken Tdap before, and it can also be taken after a severe cut or burn to prevent tetanus infection. In addition, Tdap can be safely administered at the same time as other vacines (CDC, 2021).

In addition, another factor frequently mentioned in the studies is the difficulty in obtaining proof of vaccine administration, as part of the patients did not have a history of vaccination. Tetanus seropositivity decreased to $57.3 \%$ in individuals aged 50 years and over due to the absence of reinforcement, this factor being identified as the main factor responsible for inadequate tetanus protection. The level of seroprotection, which decreases with age, becomes evident when compared to younger people, where immunity levels reach 92\% (Sahan et al., 2019; Valentino \& Rapisarda, 2001).

\subsection{Absence of vaccination campaigns}

As identified in the studies analyzed, the lack of immunization campaigns was identified as one of the factors that intervenes in vaccination coverage, since most adults are only immunized when they are injured and seek health services. This reality can be justified by the effectiveness of childhood immunization programs, resulting in the fight against neonatal tetanus and the absence of programs aimed at the elderly population, making them more susceptible. Other reasons for the lack of these possibilities were the existence of patients who sought health centers but refused to receive the vaccine, as well as the lack of encouragement from health professionals and the lack of surveillance for tetanus vaccination in many countries, for example from Turkey (Castro et al., 2004; Sahan et al., 2019; Valentino \& Rapisarda, 2001). Accordingly, superficial injuries are often treated at home, thus failing to carry out adequate prophylaxis in health services (Collins et al., 2016).

\subsection{Socioeconomic and demographic aspects}

Irregular immunization related to these factors was observed, highlighting the professions exercised by the patients, such as bricklayers, identified in 11.1\% of the studies (Castro et al., 2004; Feijão et al., 2007); farmers, in 16.7\% (Castro et al., 2004; Feijão et al., 2007; Valentino \& Rapisarda, 2001); housewife and cleaning lady, in 16.7\% (Cruz-Hervet et al., 2013; 
Feijão et al., 2007; Valentino \& Rapisarda, 2001). In addition, truck drivers, nurses and seamstresses were also seen as activities and professions more likely to contract the infection (Valentino \& Rapisarda, 2001). It is believed that individuals who exercise such professions are more susceptible to contracting tetanus, as they are constantly exposed to sharp materials and subject to various types of accidents. As well as the low level of education, which is also a factor of susceptibility to infection, since the lack of information about disease prevention is greater among this population (Cruz-Hervet et al., 2013; Sahan et al., 2019; Talan et al., 2004).

As for the place of residence, $27.7 \%$ of the studies claimed that there was a relationship between the illness and the place of residence being in the rural area (Castro et al., 2004; Cruz-Hervet et al., 2013; Moura \& Martins, 2019; Razzaghi et al., 2011; Valentino \& Rapisarda, 2001). In contrast to $11.1 \%$ who reported more infected individuals from urban areas (Feijão et al., 2007; Halperin et al., 2015). Furthermore, awareness and acceptance of national guidelines for the Tdap vaccine in adults, being an immigrant, speaking a different language from the country in which they live, and citizenship were also identified as factors capable of affecting immunization (Cruz-Hervet et al., 2013; Halperin et al., 2015; Moura \& Martins, 2019). The most frequent, appearing in $22.2 \%$ of the studies (Cruz-Hervet et al., 2013; Feijão et al., 2007; Moura \& Martins, 2019; Sahan et al., 2019), was the low socioeconomic level, which can be justified by the fact that health services are private in some countries, such as Australia, which tetanus vaccine is not available free of charge for people over the age of 50 (Castro et al, 2004; Quinn \& McIntyre, 2007).

In this context, it was identified the existence of several factors for the elderly population not to have the complete immunization scheme, which makes them more vulnerable to developing the infection. The importance of proper hygiene at the wound site with soap and water is highlighted to remove possible foreign bodies that may be present and thus avoid secondary infections from other opportunistic bacteria. Importantly, if the patient received the immunization five years ago and has a high-risk wound, it alone will not be enough. Therefore, immunoglobulin should be administered to avoid contamination by tetanus, as it provides temporary immunity until the vaccine starts to form immunizing antibodies. Thus, with the availability of a safe and effective vaccine against tetanus, what is lacking is the propagation of prophylaxis among this public in order to overcome the protection deficit and guarantee a reduction in the number of cases notified or not.

\section{Conclusions}

It is concluded that tetanus is a disease that can cause serious complications and concerns to public health systems, with the elderly population being the population most affected by the infection, both due to changes in their physiology and reduction of their functional capacity, as well as the decrease in levels of protective antibodies provided by the vaccine. Thus, it contributes to the high incidence of new cases and high lethality rate, since there are several aspects capable of interfering with vaccination coverage.

After analyzing the studies in the scientific literature, factors that affect the tetanus vaccination status in the elderly were identified: Incomplete Vaccination, Absence of Vaccination Campaigns and Socioeconomic and Demographic Aspects.

Given the above, the need to develop public policies aimed at raising awareness and reversing the problem of low immunization rates is highlighted, as well as government actions, such as the development of a system or application in which the population could have easy access to the complete and updated vaccination calendar, having knowledge of their vaccination status, as many individuals do not have the means to prove immunization. Thus, professionals would have more control and ease in directing and building vaccine campaigns aimed at preventing new cases and, consequently, reducing the lethality rate in the elderly population, promoting improvements in their quality of life. 
The importance of this bibliographical research is also highlighted as a way to systematize and provide an analysis of the research carried out in a certain time frame. Through this review of the current literature, it is expected to contribute to the increase and dissemination of information in this area, in addition to stimulating new scientific studies on this issue, which is sometimes neglected. Emphasizing the importance of carrying out future research with recent data on the problem, seeking to investigate the immunization schedules of the elderly public, as well as the reach of vaccination campaigns and implementation of health education programs, aiming to expand access to information, bringing them closer to reality and making them aware of the benefits of immunization as a form of prevention.

\section{References}

Castro, L., Gonçalves, G., \& Catarino, J. (2004). Caracterização epidemiológica dos casos declarados de tétano. Oportunidades perdidas de vacinação. Acta Med Port, 17 (3), 225-9.

CDC - Centers for Disease Control and Prevention (2021). DTaP (Diphtheria, Tetanus, Pertussis) Vaccine: What You Need to Know. https://www.immunize.org/vis/dtap.pdf

Collins, S., Amirthalingam, G., Beeching, N. J., Chand, M. A., Godbole, G., Ramsay, M. E., Fry, N. K., \& White, J. M. (2016). Current epidemiology of tetanus in England, 2001-2014. Epidemiology \& Infection, 144 (16), 3343-3353.

Cossutta, F. (2017). Programa Nacional de Vacinação 2017 e vacinação antitetânica. Revista Portuguesa de Medicina Geral e Familiar, 33 (6), $420-4$.

Cruz-Hervert, L. P., Ferreira-Guerrero, E., Díaz-Ortega, J. L., Trejo-Valdivia, B., Téllez-Rojo, M. M., Mongua-Rodríguez, N., Hernández-Serrato, M. I, Montoya-Rodríguez, A. A., \& García-García, L. (2013). Cobertura de vacunación en adultos y adultos mayores en México. Salud pública de méxico, 55, S300-S306

Domínguez, A., Plans, P., Costa, J., Espuñes, J., Cardeñosa, N., Salleras, L., \& Plasència, A. (2007). The seroepidemiology of tetanus in Catalonia, Spain. Medical microbiology and immunology, 196 (2), 115-119.

Farnworth, E., Roberts, A., Rangaraj, A., Minhas, U., Holloway, S., \& Harding, K. (2012). Tetanus in patients with chronic wounds-are we aware? International wound journal, 9 (1), 93-99.

Feijão, A. R., Brito, D. M. S. D., Peres, D. A., \& Galvão, M. T. G. (2007). Tétano acidental no Estado do Ceará, entre 2002 e 2005. Revista da Sociedade Brasileira de Medicina Tropical, 40, 426-430.

Filia, A., Bella, A., Von Hunolstein, C., Pinto, A., Alfarone, G., Declich, S., \& Rota, M. C. (2014). Tetanus in Italy 2001-2010: a continuing threat in older adults. Vaccine, 32 (6), 639-644.

Halperin, B. A., MacDougall, D., MacKinnon-Cameron, D., Li, L., McNeil, S. A., Langley, J. M., \& Halperin, S. A. (2015). Universal tetanus, diphtheria, acellular pertussis (Tdap) vaccination of adults: What the Canadian public knows and wants to know. Vaccine, 33 (48), 6840-6848.

Mahieu, R., Reydel, T., Maamar, A., Tadié, J. M., Jamet, A., Thille, A. W., Chudeau, N., Huntzinger, J., Grangé, S., Beduneau, G., Courte, A., Ehrmann, S., Lemarié, J., Gibot, S., Darmon, M., Guitton, C., Champey, J., Schwebel, C., Dellamonica, J., Wipf, T., Meziani, F., Cheyron, D. D., Kouatchet, A., \& Lerolle, N. (2017). Admission of tetanus patients to the ICU: a retrospective multicentre study. Annals of Intensive Care, 7 (1), 1-7.

Mendes, K. D. S., Silveira, R. C. D. C. P., \& Galvão, C. M. (2008). Revisão integrativa: método de pesquisa para a incorporação de evidências na saúde e na enfermagem. Texto \& contexto-enfermagem, 17, 758-764.

Ministério da Saúde. (2015). Informe Epidemiológico do tétano acidental no Brasil. Brasília. https://portalarquivos2.saude.gov.br/images/pdf/2016/julho/28/BR-Informe-TA-2015.pdf.

Ministério da Saúde. (2017). Tétano Acidental: Guia de Vigilância em Saúde. 171-80.

Ministério da Saúde. (2018). Boletim Epidemiológico: Situação epidemiológica do tétano acidental no Brasil, 2007-2016. 49 (5), 1-15.

Ministério da Saúde. (2019). Instrução normativa referente ao calendário nacional de vacinação, Brasília. https://portalarquivos2.saude.gov.br/images/pdf/2019/abril/24/Site-Instrucao-Normativa-Calendario-.pdf.

Moraes, E. N. \& Pedroso, E. R. P. (2000). Tétano no Brasil: doença do idoso?. Rev Soc Bras Med Trop., 33 (3), 271-5.

Moura, S., \& Martins, M. D. R. O. (2019). Determinants of tetanus vaccination among adult immigrants: findings from the Portuguese national health survey 2014. International journal of environmental research and public health, 16 (9), 1619.

Organização Pan-Americana de Saúde. (2019). Eliminação do tétano materno e neonatal. Washington: OPAS/OMS.

Quinn, H. E., \& McIntyre, P. B. (2007). Tetanus in the elderly—An important preventable disease in Australia. Vaccine, 25 (7), 1304-1309.

Razzaghi, R., Khalifesoltani, A., Heravi, M. M., \& Akbari, H. (2011). Tetanus immunity in individuals aged 50 years or older in Kashan, Iran. Acta Medica Iranica, 379-382. 
Research, Society and Development, v. 11, n. 3, e14911326226, 2022

(CC BY 4.0) | ISSN 2525-3409 | DOI: http://dx.doi.org/10.33448/rsd-v11i3.26226

Sahan, S., Demirbilek, Y., Sonmez, C., Temel, F., \& Sencan, I. (2019). Epidemiological study of tetanus seropositivity levels in different age groups in Ankara province, Turkey, 2017. Japanese Journal of Infectious Diseases, 72 (1), 14-18.

Souza, M. T. D., Silva, M. D. D., \& Carvalho, R. D. (2010). Revisão integrativa: o que é e como fazer. Einstein (São Paulo), 8, 102-106.

Talan, D. A., Abrahamian, F. M., Moran, G. J., Mower, W. R., Alagappan, K., Tiffany, B. R., Pollack, C. V., Steele, M. T., Dunbar, L. M., Bajani, M. D., Weyant, R. S., \& Ostroff, S. M. (2004). Tetanus immunity and physician compliance with tetanus prophylaxis practices among emergency department patients presenting with wounds. Annals of emergency medicine, 43 (3), 305-314.

Tavares, W., \& Marinho, L. A. C. (2005). Rotinas de diagnóstico e tratamento das doenças infecciosas e parasitárias. São Paulo, SP: Editora Atheneu.

Valentino, M., \& Rapisarda, V. (2001). Tétano em uma região central da Itália: possibilidade de prevenção mais eficaz entre trabalhadores agrícolas não vacinados. Medicina do Trabalho, 51 (2), 114-117.

Weckx, L.Y., K. Divino-Goes, K., Lihama, D.M., Carraro, E., Bellei, N., Granato, C.F.H., Moraes-Pinto, M.I. (2006). Effect of a single tetanus-diphtheria vaccine dose on the immunity of elderly people in São Paulo, Brazil. Brazilian Journal of Medical and Biological Research [online], 39(4), 519-523. https://doi.org/10.1590/S0100-879X2006000400012.

Weinberger, B., Schirmer, M., Matteucci Gothe, R., Siebert, U., Fuchs, D., \& Grubeck-Loebenstein, B. (2013). Recall responses to tetanus and diphtheria vaccination are frequently insufficient in elderly persons. PloS one, 8 (12), e82967. 